\title{
Etnicitet mellem produktion og skole
}

\author{
Tanja Kirkegaard, Klaus Nielsen \& Kasper Østergaard Linde
}

\begin{abstract}
På baggrund af et interview- og observationsstudie af produktionsskoleelever på tre forskellige produktionsskoler vil vi i denne artikel pege på, hvorledes praktiske arbejdsfællesskaber giver andre deltagelsesmuligheder for etniske minoritetselever sammenlignet med undervisningssituationer tilrettelagt på mere traditionel skolastisk vis. Vi vil pege på, at den traditionelle undervisning, hvor sproglig interaktion fungerer som det organiserende princip, ikke altid formår at matche etniske minoritetselevers dansksproglige forudsætninger, hvilket kan bidrage til at fremstille etniske minoritetselever som knapt så intellektuelt velfungerende. Dette kommer både til udtryk gennem undervisningsformerne og undervisningsmaterialerne. De mere praktiske arbejdsfællesskaber, som er dominerende på produktionsskolerne, synes i højere grad at positionere etniske minoritetselever som mere velfungerende, idet sprogbrugen her i højere grad nærmer sig dagligdagssprog, og de etniske minoritetselever får langt større muligheder for at bruge deres læringserfaringer fra andre kontekster end skolekontekster.
\end{abstract}

Keywords: observation; produktionsskoler; etniske minoriteter; sproglig interaktion.

Please cite this article as:

Kirkegaard, T., Nielsen, K. \& Linde, K. Ø. (2011). Etnicitet mellem produktion og skole. Qualitative Studies, 2(1): 50-62.

\section{Introduktion}

Læreren spørger: "Hvordan kan man se, om en person trækker vejret?" Han henvender sig til Samira1. Hun ser forvirret ud og siger: "Det ved jeg ikke". Læreren: "Det er jo ikke jordens sværeste gåde". Hun kigger ned i bordet og forsøger at gentage nogle af ordene for at forstå sammenhængen. Alle har rettet deres blik mod hende. En af de andre rækker hånden op og svarer på det. Hun kigger undskyldende på de andre elever.

Vi vil i denne artikel tematisere etnicitet i uddannelsessystemet med særligt udgangspunkt i en undersøgelse, som vi har gennemført om læring i en produktionsskolepraksis (Kirkegaard \& Nielsen, 2008). Artiklen vil primært beskæftige sig med de erhvervsrettede ungdomsuddannelser med udgangspunkt i produktionsskolen. I den forbindelse er spørgsmålet om etnicitet blevet centralt, fordi antallet af unge med anden etnisk baggrund på produktionsskolerne og erhvervsuddannelserne er stigende. Antallet af unge med anden etnisk baggrund end dansk, der påbegynder en erhvervsuddannelse er fordoblet de seneste ti år (UVM, 2007), og antallet af etniske minoritetsunge udgør en voksende andel af de unge, som ikke færdiggør en ungdomsuddannelse (Gudmundsson \& Jensen, 2005).

På baggrund af en empirisk undersøgelse vil vi pege på, hvorledes undervisningssituationer, som baserer sig på traditionel sproglig instruktion, i visse sammenhænge kan bidrage til at positionere etniske minoriteter som mindre velfungerende, mens undervisningssituationer funderet i mere praktiske arbejdsfællesskaber derimod synes at positionere denne gruppe som mere velfungerende. Vi ønsker at pege på, at forskellige organiseringer af undervisningen kan

\footnotetext{
${ }^{1}$ Alle person- og stednavne i artiklen er pseudonymer.
} 
give forskellige deltagelsesmuligheder for eleverne og dermed forskellige muligheder for at positionere sig. Baggrunden for denne forskel i deltagelsesmuligheder vil vi argumentere for til dels - skal findes i sproget som organisatorisk princip, men også i de etniske minoriteters muligheder for at inddrage læringserfaringer fra andre kontekster. Artiklen søger således at pege på, at den måde undervisningssituationer organiseres på har betydning for, hvordan eleverne fremstår som eksempelvis mere eller mindre velfungerende.

Det er vigtigt at understrege at vores fokus i denne artikel er på elever med etnisk minoritetsbaggrund, som grundet deres sprogforståelsesproblemer bliver marginaliseret som deltagere i undervisningssituationer, der er organiseret med udgangspunkt i en akademiseret sprogpraksis, mens de i højere grad kan opnå status som legitime deltagere i mere praktiske arbejdsfællesskaber. Endvidere er det vigtigt for os at pointere, at vi naturligvis ikke finder, at elever med etnisk minoritetsbaggrund er mere praktisk anlagte end danske elever, eller at danske elever er mere bogligt anlagte end etniske minoritetselever. I forhold til sproget illustrerer ovenstående eksempel, hvorledes etnicitet bliver sat $i$ spil $i$ en undervisningssituation. Samira kommer i den ovenfor beskrevne undervisningssituation til at fremstå som mindre velfungerende, end hun faktisk er, da den sproglige organisering af læringssituationen, hvor der stilles et særpræget og indlysende spørgsmål, får spørgsmålet til lyde mere kompliceret, end det i virkeligheden er. Samspillet mellem spørgsmålets banale karakter og Samiras svage dansksproglige forudsætninger medfører, at hun føler sig positioneret som dårligt fungerende i læringssituationen.

Megen moderne uddannelsestænkning bygger på en tanke om, at sproglig instruktion skal være omdrejningspunktet for at kunne kvalificere til at kunne betegnes som undervisning (Schön, 1983; Schön, 1987). Det er ganske enkelt blevet en selvfølgelighed, at pædagogiske interventioner er bygget op omkring sproglighed. Diskussionen af sproglighed og den akademisering, der følger med sprogliggørelsen af en given uddannelsespraksis, har været genstand for en del diskussion (se eksempelvis Wackerhausen, 1999). I de senere år er der kommet en del etniske minoriteter ind i det danske uddannelsessystem, hvoraf en vis andel har vanskeligheder med at beherske det danske sprog. Det er paradoksalt, at der på den ene side sker en voldsom akademisering af uddannelsessystemet i dag, også omfattende de erhvervsrettede ungdomsuddannelser (Sigurjonsson, 2002), og på den anden side, at man forsøger at integrere store grupper elever med anden etnisk baggrund end dansk i uddannelsessystemet. Det betyder, at i en række situationer i uddannelsessystemet, hvor undervisnings- eller prøvesituationer primært hviler på en ofte akademiseret sproglig formidling, tages der ikke altid højde for de etniske minoritetselevers ofte svage dansksproglige forudsætninger, og dermed står de etniske minoritetselever i en vanskeligere situation end danske elever. Det vil sige, at der er nogle situationer, hvor det bliver særligt tydeligt, at mennesker med en anden etnisk baggrund fremstår som mindre intellektuelt velfungerende. Frem for at betragte personer med anden etnisk baggrund som personer, der har vanskeligt ved beherske det danske sprog i almindelighed og derfor også har vanskeligheder med det akademiserede sprog i uddannelsessystemet i særdeleshed, så kommer de til at fremstå som elever, der ikke er så intellektuelt velfungerende som danske elever.

Omvendt synes eleverne i situationer, der er opbygget omkring praktiske arbejdssituationer at fremstå som elever, der har færre problemer og flere ressourcer at trække på. Praktiske arbejdssituationer organiseres i mindre grad omkring et akademiseret sprogbrug, men i højere grad omkring brugen af dagligdagssprog og en kropslig og mimetisk praksis, hvilket gør at 
nogle elever med anden etnisk baggrund kan udvikle deres erfaringer i disse sammenhænge, samt trække på konkrete erfaringer, som de selv eller andre gør sig i arbejdssituationen.

I denne artikel vil vi særligt fokusere på frafaldsproblematikken, netop fordi en af konsekvenserne af at blive positioneret som mindre velfungerende i uddannelsesmæssige sammenhænge driver mange unge $\mathrm{i}$ retning af at opgive deres uddannelse (Alexander \& Entwistle, 2001).

I artiklen benytter vi os af en situeret tilgangsvinkel til læring og uddannelse, hvor det er en kongstanke, at vi deltager og er medskabere af en række praksissammenhænge, som er medbestemmende for, hvordan vi lærer, og hvad vi lærer (Lave \& Wenger, 2003, Pedersen, 2006). Fra et situeret perspektiv er det ikke tilstrækkeligt at fokusere på individerne og deres læring, men vi må også se på, hvordan praksis er tilrettelagt for at forstå læringsressourcer og læringsbarrierer (Nielsen \& Kvale, 2006). Man kan sammenligne en social praksis med at bebo et gammelt hus, hvor man ikke længere lægger mærke til rummene, husets opdeling, trappen der knirker osv. Man lægger kun mærke til de mennesker, som bor i huset og de, der kommer på besøg (Varenne \& McDermott, 1999). Lidt det samme kan siges om uddannelsesinstitutioner, hvis vi sammenligner dem med sociale praksisser. Vi glemmer, at de er lagt tilrette således, at det passer særligt på elever med en dansksproglig grundkompetence, og vi tilrettelægger undervisningssituationer primært på baggrund af sproglig formidling.

\section{Etnicitet og frafald}

En del af den hidtidige forskning omkring etniske minoriteter inden for uddannelsesområdet har overvejende fokuseret på de problemer, der opstår, når unge med anden etnisk baggrund møder det danske uddannelsessystem i forhold til uddannelsesvalg og frafald. Langt de fleste publicerede undersøgelser af hvordan elever med anden etnisk baggrund klarer sig i det danske uddannelsessystem arbejder ud fra et kvantitativt sociologisk perspektiv (se eksempelvis Colding, 2005; Jensen, P. \& Tranæs, T, 2007). Der findes relativt få publikationer af større danske kvalitative undersøgelser, der beskæftiger sig med, hvordan det går elever med anden etnisk baggrund i det danske uddannelsessystem. I det følgende vil vi nævne et par kvalitative undersøgelser, der sætter fokus på området. I en undersøgelse, der fokuserede på etnicitet og køn, fulgte Staunæs (2004) eleverne i to syvende klasser på to kommuneskoler i en forstad til København. Staunæs (2004) viste i sin undersøgelse, hvordan kategorierne køn, etnicitet og seksualitet gennemkrydser og gensidigt påvirker hinanden i elevernes subjektiveringer og subjektiveringstilbud. I sin analyse fremhævede Staunæs (2004) "hvordan køn og etnicitet på forskellig vis bliver til i skolen hver dag, som en del af de tolkningsrammer, skolens aktører forstår sig selv og hinanden igennem" (p. 30). I analysen fungerer etnicitet og køn som 'performance', ikke som noget, man er, men noget, man gør og bliver hver dag. Endvidere analyseres også læreres holdninger og skolernes politikker af de subjektiveringsmuligheder, eleverne har til rådighed. Mørch (2003) viste $i$ en interviewundersøgelse af personer med etnisk minoritetsbaggrund, der går på erhvervsskole, hvordan marginaliseringen sættes i værk i en uddannelsesmæssig hverdag, og hvordan den fastholdes og udvikler sig til en selvforstærkende cirkel. I analysen gives der gode eksempler på, hvordan to lærlinge delvist søger at overskride marginaliseringen ved at udvikle særligt forholdemåder ("at udholde ydmygelsen", "at fornægte sig selv" etc.) i forhold til den marginaliserende praksis, som de konfronteres med. Begge undersøgelser er interessante, men de sætter kun i begrænset omfang fokus på, hvordan de forskellige kontekster er organiserede og hvordan denne organisering influerer på deltagernes handlemuligheder og sociale positioneringer. En tematik, som er central for denne artikel. 
I denne artikel vil vi ligeledes sætte fokus på frafaldsproblematikken. Der er en klar tendens til, at etniske minoriteter i højere grad falder fra ungdomsuddannelserne. Det er specielt inden for erhvervsuddannelserne, at frafaldet er stort blandt etniske minoriteter. Det største frafald findes blandt mænd med anden etnisk baggrund end dansk, hvor frafaldet her er oppe på $60 \%$ inden for visse uddannelser (Koudahl, 2005). For kvinder med anden etnisk baggrund end dansk ligger frafaldet afhængig af uddannelse inden for erhvervsuddannelserne på mellem $20 \%$ og 52 \% (Ibid.). Forskning om årsager til etniske minoriteters frafald fra erhvervsuddannelserne er sparsom. Derimod er der adskillige rapporter omkring årsager til frafald på erhvervsuddannelser (Koudahl, 2005), hvor der er en tendens til at fokusere på strukturelle og individuelle forhold, mens samspilsmæssige forhold i mindre grad er undersøgt.

Af de strukturelle årsager til frafald peger forskningen på, at uddannelsesorganiseringen er medvirkende til at skabe frafald, hvor organisering af undervisningsform (Ministeriet for Flygtninge, Indvandrere og Integration [MFII], 2005), undervisningsindhold (Ibid.), dårlig kontakt mellem erhvervsskole og praktikvirksomheden (Andersen, 2005) samt mangel på praktikpladser (Analyseinstituttet Instant Answer, 2004; Smith \& Jacobsen, 2000; Mehlbye et al., 2000; MFII, 2005) bliver nævnt som årsager til frafald. Specifikt i forhold til etniske minoriteter synes manglen på praktikpladser og undervisningsindholdet at udgøre det største problem. De unge peger selv på, at det faglige niveau i erhvervsuddannelserne er for højt i nogle af fagene (MFII, 2005).

De individfokuserede årsager til frafald knytter sig bl.a. til personlige problemer (Analyseinstituttet, 2004), eksempelvis at de frafaldstruede elever har en "kort lunte" i forhold til problemer på uddannelsen (Brock \& Gonnsen, 2004). Specifikt i forhold til etniske minoriteter nævnes, at de etniske minoriteter har dårligere faglige kvalifikationer såsom dårligere danskkundskaber (Schmidt \& Jacobsen, 2000; Mehlbye et al., 2000; Andersen, 2005; MFII, 2005), hvilket bruges som forklaringsbaggrund på frafaldet. Derudover er der peget på, at etniske minoriteter i højere grad har svært ved selvstændige arbejdsformer, og at de stillede opgaver skal være meget konkrete og tilbagemeldingen til dem skal være konkret og præcis (MFII, 2005). Der er blevet udledt en række forhold som synes at have betydning for, om de etniske minoriteter får en erhvervskompetencegivende uddannelse eller ej, såsom at unge med anden etnisk baggrund skriver for få uopfordrede ansøgninger, mangler socialt netværk, bliver nødt til at arbejde, er skoletrætte eller at de prioriterer børn og familie (Schmidt \& Jacobsen, 2000). Endvidere er det blevet fremhævet, at det især er de etniske minoritetselever, der føler sig isolerede i forhold til de danske elever (MFII, 2005).

I vores undersøgelse har vi ønsket at se på de mere specifikke sociale samspilssituationer, der foregår på produktionsskolerne, og derfor har en del af vores dataindsamlingsmetode været deltagende observation på skolerne. Den deltagende observation er kun et element af dataindsamlingen i forskningsprojektet om læring i produktionsskoleregi. I forbindelse med forskningsprojektet er der gennemført 110 strukturerede interviews med elever fra tre forskellige produktionsskoler. Ud fra disse interviews blev 5 elever udvalgt og herefter fulgt over en periode på 2 måneder med observation og semi-strukturerede interviews. Det var både elever såvel som lærere, der blev interviewet. Den deltagende observationsmetode er velegnet til at fokusere på interaktionen mellem forskellige aktører og den giver et godt indblik i de forskellige aktørers positionering, identiteter og handlestrategier $\mathrm{i}$ forhold til hinanden (Järvinen \& Mik-Meyer, 2005). I undersøgelsen sætter vi fokus på samspillet mellem nogle elevers manglende mestring af det danske sprog og bestemte typer sprogligt organiserede læringssituationer, og det ville derfor være paradoksalt, hvis vi alene benyttede os af 
spørgeskema- og interviewteknikker, der netop forudsætter gode sprogkundskaber. Derudover havde flere af de etniske minoritetselever en udpræget defensiv og mistroisk indstilling til interviews og spørgeskemaer, som i kombination med mulige sprogproblemer og usikkerheder yderligere ville have problematiseret vores bestræbelse på at indsamle viden.

\section{Produktions-skole}

I Danmark er der 99 produktionsskoler, og på landsplan var antallet af årselever ${ }^{2}$ på produktionsskolerne i 20046.929 elever, og der var 14.224 deltagere ${ }^{3}$, hvoraf $60 \%$ af deltagerne var mænd (UVM, 2004). Produktionsskolen er organiseret på en ganske særlig måde, som det fremgår af orddelingen i afsnitsoverskriften. Produktionsskolen er på den ene side tilrettelagt således, at eleverne både indgår $\mathrm{i}$ produktionsværksteder, som er organiseret mesterlæreorienteret og rettet mod, at eleverne lærer at håndtere bestemte praktiske færdigheder. På disse værksteder arbejder erfarne håndværkere, og det er målet, at de produkter, der frembringes, skal sælges. På de forskellige produktionsskoler er der forskellige typer af værksteder alt efter produktionsskolens profil. På den anden side er produktionsskolen også en skole, hvor eleverne kan/skal deltage i bestemte former for traditionel undervisning. Nogle steder er der obligatorisk undervisning og andre steder er der valgfri undervisning. På alle skoler er der teoriundervisning, men det foregår ikke nødvendigvis som traditionel undervisning. Det vil sige, at produktionsskolen rummer skismaet mellem traditionel undervisning og praktiske oplæringsformer.

Skismaet mellem hvad eleverne skal kunne og deres dygtighed fanges i følgende ordveksling mellem undertegnede (TK), en leder på produktionsskolen og en lærer, der bryder ind. Samtalen drejer sig om en elev med anden etnisk baggrund:

Forstanderen på produktionsskolen Randumsholm spurgte, hoordan jeg synes det var på mekanikværkstedet. Jeg sagde, at det var spændende at være der, og at jeg var meget imponeret over, hvor dygtig Razim var til arbejdet. Forstanderen var enig og sagde, at det var utroligt det, han kunne med sine hænder. En lærer der underviste i dansk og matematik på skolen afbrød og sagde:" Ja, det er godt nok, men han kan ikke sætte 3 bogstaver sammen".

Eksemplet peger på skismaet mellem at være dygtig til det faglige i en meget praktisk forstand på den ene side og være dygtig til det mere boglige på den anden side. Som det vil fremgå af vores eksempler i det følgende, er dette skisma særdeles centralt i forbindelse med etnicitet og er på forskellig måde med til at positionere eleverne som mere eller mindre velfungerende. Produktionsskolerne repræsenterer en sammentænkning af arbejdspladsoplæring og institutionaliseret skoleundervisning og er ganske unikke i moderne uddannelsestænkning. De eksempler, vi i det følgende benytter os af, bygger på disse observationer og interviews og peger på skismaet mellem sprogligt formidlede instruktionssituationer og praktiske instruktionssituationer.

\section{Sproglig instruktion og etnicitet}

I vores materiale viser det sig, at i en række situationer bliver manglen på sproglige evner eller kulturelle forudsætninger forvekslet med manglende intellektuelle evner hos elever med en anden etnisk baggrund. I vores materiale er der en del eksempler på, hvordan de pædagogiske situationer

\footnotetext{
2 Med årselever menes elever, der har været indskrevet på skolen i 40 uger

${ }^{3}$ Med deltagere menes elever, der er indskrevet på produktionsskolen i mindre end 40 uger
} 
næsten udelukkende er bygget op over sproget som central instruktionsskabelon. I det følgende giver vi tre eksempler på, hvordan samspillet mellem forskellige typer af sprogligt baserede instruktionssituationer og elevernes forskellige sproglige vanskeligheder medvirker til at positionere deltagerne som dårligt fungerende.

Det første eksempel peger på en problematik, hvor en forvirrende og ustruktureret sprogligt formidlet instruktion i samspil med en elevs dårlige almene dansksproglige forudsætninger er med til at skabe en forståelse af eleven som mindre velfungerende, end hun måske i virkeligheden er. Vi er på et syværksted på Søby Produktionsskole, hvor hjælpelæreren forklarer eleven Fatima, som har været i Danmark i tre år og derfor ikke forstår dansk særlig godt, hvordan hun skal skære stof ud.

Hjælpelæreren siger til Fatima: "Nu er det din tur, så du skal gøre det samme som Mathilde (en anden elev)". Jeg (TK) stod og tænkte, at jeg var blevet ret forvirret over den tidligere episode og ville ikke selv vide, hvad jeg skulle gøre, så jeg var spændt på, om Fatima, som kom fra en modtagerklasse og havde svart ved det danske sprog, havde forstået noget af det hjælpelæreren havde forklaret. Men hun begyndte at måle $42 \mathrm{~cm}$ op. Hun blev hurtigt afbrudt af læreren, de havde til daglig: "Du må ikke begynde $2 \mathrm{~cm}$ oppe. Det er spild af stof. Du skal starte forneden. Sådan noget stof er meget dyrt. $400 \mathrm{kr}$. meteren". Hjælpelæreren træder til: "Ja det er meget dyrt. Se så meget stof der går til spilde ellers". Fatima bliver nervøs og kigger usikkert på lærerne. Så går hun helt ned til kanten af stoffet og begynder at måle $42 \mathrm{~cm}$ op og trækker en streg helt nede ved kanten af stoffet. Hun bliver igen afbrudt af hjælpelæreren: "Du skal ikke trække en streg forneden. Det kan ikke betale sig. Du skal bare måle op". Hun holder op med at trække stregen og kigger forvirret op på hjælpelæreren. "Du skal bare måle op". Fatima måler $42 \mathrm{~cm}$ og sætter en streg ved $42 \mathrm{~cm}$.

Hjælpelæreren stopper hende igen. "Du skal ikke måle $42 \mathrm{~cm}$ op her. Du kan godt se, at hvis du måler 29 cm op i stedet for, kan der vare 2 af dem. Så du skal måle $29 \mathrm{~cm}$ op to gange".

Jeg (TK) er selv ret forvirret på det tidspunkt. Fatima måler to gange $29 \mathrm{~cm}$ op og kigger usikkert på hjælpelæreren. "Ja, og så skal du måle $42 \mathrm{~cm}$ opad. Hun måler $42 \mathrm{~cm}$ ud og sætter en streg. Så skal du gøre det igen herhenne. Det gør hun så. "Og så skal du sætte en lang streg her". Jeg (TK) tænker, at hun ikke på noget tidspunkt får en længere forklaring på, hvorfor hun skal gøre det, hun gør, og det gør det svært selv at tænke sig frem til, hoordan man skal gøre. Fatima lægger linealen og begynder at trække en streg, men pludselig trækker hun stregen meget skævt og flere centimeter over linealen. Både hjælpelæreren og læreren råber et meget højt "uh!" og begynder at grine. Fatima bliver forskrækket og ser flov ud. Hun kigger undskyldende på mig og griner genert.

Hjxlpelæreren går ned $i$ den anden ende af lokalet og kalder mig ned til sig. "Ja, du kan godt se, at det er nogle svage elever, vi har med at gøre. Når de ikke engang kan måle simple mål op eller trække en streg på et stykke stof, så er der lang vej." (...)"Den der med, at alle skal i uddannelse - den går bare ikke, for der er elever, der er for svage til at få en uddannelse. Alle de ufaglærte jobs er forsvundet, og så er der ikke noget at gøre for dem."

I denne observation viser det sig, at den elev, som lærerne her betegner som en svag elev, har vanskeligt ved at forstå den instruktion, der gives fra lærerside. Der er altså ikke tale om en intellektuelt mindre velfungerende elev, men derimod tale om en elev, der har et begrænset dansk ordforråd og er usikker i forhold til at udtrykke sig på dansk. Det er altså ikke, som antydet af lærerne, på grund af en mulig intellektuel svaghed hos Fatima, at hun har vanskeligt ved at forstå, hvad det er, hun skal gøre og hvorfor, men nærmere på grund af det uhensigtsmæssige samspil mellem en uklar sproglig instruktion, som ikke møder Fatima på 
hendes sproglige præmisser. Den forvirrende og ustrukturerede verbale instruktion fører til uklarheder, og det ender med, at eleven med svage danskkundskaber bliver positioneret som dårligt intellektuelt fungerende, fordi hun har vanskeligt ved at forstå de instruktioner, der gives i situationen.

I vores empiriske materiale er der en del eksempler af samme karakter, hvor lærerne former den pædagogiske situation således, at den alene hviler på, at elever med anden etnisk baggrund skal afkode situationen på baggrund af forskellige typer af verbal instruktion, der dog ofte ikke matcher elevernes dansksproglige forudsætninger. Der er naturligvis ikke tale om ond vilje fra lærernes side, men der er derimod tale om pædagogisk rygmarvstænkning, hvor lærerne per automatik opbygger den pædagogiske situation næsten udelukkende på baggrund af en sproglig formidling.

Det er ikke kun i den verbale kommunikation, at den pædagogiske situation er baseret på sproglige instruktioner. Det er også tilfældet, når det drejer sig om mere officielt skriftligt materiale. Det andet eksempel er således hentet fra en situation, hvor læreren Søren er sammen med tre drenge af anden etnisk oprindelse end dansk i en prøvesituation. Søren læser prøvens spørgsmål op, men de er formuleret på et vanskeligt og akademisk dansk:

"Hvilke arbejdsmiljøforanstaltninger skal implementeres ved svejsning og termisk skæring?" Der var helt stille. Så forsøgte Søren at oversætte spørgsmålet, men det var stadig svart at forstå. Der var for mange udtryk, der skulle oversættes og forklares, så det blev forvirrende. Jeg kigger på Muhammed. Han ser opgivende ud og gemmer sig $i$ sin hættetrøje, mens han kigger ned. Søren prover igen, men alle ser desorienterede ud. Muhammed begynder at lofte bordet lige så stille, så tingene er ved at vxlte af det. "Hold nu op Muhammed", siger Søren. Muhammed sukker og kigger ud i luften. Han spørger, om de ikke kan holde en pause. Søren kigger på uret og siger "jo".

Eksemplet peger på, at prøven i arbejdsmiljø er formuleret i et akademiseret sprog, og det er vanskeligt for de etniske minoritetsunge at forstå, hvad der egentligt spørges til. Det viser sig efterfølgende, at når Muhammed og de andre unge får forklaret rationalet bag spørgsmålet ved at Søren henviser til den daglige praksis på værkstedet, dvs. når spørgsmålet formuleres i et mere fleksibelt dagligdagssprog, så kan eleverne relativt nemt svare på spørgsmålet. Det er således ikke blot i konkrete verbalt baserede undervisningssituationer, at eleverne kan have vanskeligheder. Også den akademiserede formulering af et skriftligt prøvemateriale kan være medvirkende til at positionere de her beskrevne elever med anden etnisk baggrund, som mindre intellektuelt velfungerende, end de i virkeligheden er. Problemerne udspringer af et uhensigtsmæssigt samspil mellem et akademiseret undervisningsmateriale, der ikke tager højde for elevernes præmisser, og elevernes i den henseende svage danksproglige forudsætninger. Denne sammenblanding medvirker, ligesom i indledningseksemplet, til at fremstille elevernes intellektuelle funktion som mindre velfungerende.

Afslutningsvist vil vi pege på, at det ikke kun er et vanskeligt og ofte akademisk dansk, der positionerer de etniske minoritetsunge, som svagt fungerende. Vi observerede i flere tilfælde, at det var problematisk, at en del af det materiale eleverne med etnisk minoritetsbaggrund arbejder med, er tilpasset danske elever på ganske bestemte alderstrin. Det betyder i praksis, at unge med anden etnisk baggrund ender med at skulle læse børnebøger eftersom deres sproglige niveau matcher en yngre dansk elev, hvilket positionerer de etniske minoritetsunge som elever, der er 'mindreårige', hvilket naturligvis i flere tilfælde gav anledning til, at de valgte at gå i opposition til den position, som blev tilbudt dem. 
Ali sidder uroligt og ser ikke ud til at kunne koncentrere sig. Hans bog er en letlæsningsbog skrevet til mindre børn. Han rømmer sig og laver spyttelyde for at få de andres opmærksomhed, og det virker.(..) Jeg talte lidt med læreren om manglen på passende undervisningsmateriale. Han fremhæver, at der mangler noget materiale med en lav sværhedsgrad, som alligevel passer til deres aldersgrupper.

Eksemplet viser, at Ali, som er seksten år gammel, bliver nødt til at sidde og læse en bog for mindreårige børn. Det er nedværdigende for Ali at sidde med en letlæsningsbog for mindreårige børn, og det er heller ikke noget, der giver ham særlig stor status i de andres øjne. Derfor ender det også med, at Ali begynder, at lave 'ballade' for at bryde sin positionering, som 'mindreårig'. I dette tilfælde er undervisningsmaterialet på et 'formniveau' bedre i overensstemmelse med elevens dansksproglige forudsætninger. Men på et 'indholdsniveau' er lærebogsmaterialet stadig problematisk, eftersom det er rettet mod yngre børn og derfor ikke er alderssvarende for Ali. Dermed sættes ikke kun Alis intellektuelle funktion på spil, men også hans stolthed og værdighed, hvilket han reagerer på med problemadfærd. Begge aspekter medvirker til at positionere ham som mindre velfungerende.

I de ovenstående eksempler er der således skitseret en række skolesituationer, hvor eleverne stilles overfor en række skolemæssige krav, der har det til fælles, at de hviler primært på en forholdsvis ufleksibel sproglig instruktion og formidling, der ikke formår at tage udgangspunkt i eller højde for de etniske minoritetselevers dansksproglige forudsætninger. Disse eksempler på ikke-tilpasset sproglig instruktion og formidling medvirker utilsigtet til at positionere de etniske minoritetselevers mindre intellektuelt velfungerende. I og med sproget får en afgørende rolle i forhold til undervisningssituationen, så har eleverne vanskeligt ved at honorere disse krav og vælger dermed enten at resignere eller bevæge sig i retning af ballademagerrollen.

At elevernes frembragte svagheder og problemer imidlertid ikke, som det fremgår af analysen af eksemplerne, kan betragtes $\mathrm{i}$ isolation, eller som personlige egenskaber hos eleverne, men $\mathrm{i}$ højere grad må ses som resultat af en uhensigtsmæssig organisering af undervisningssituationer medinddrages ikke i forståelsen af de problemer, der opstår. Pædagogisk set får det den konsekvens, at de etniske minoritetselevers vanskeligheder ikke opfattes som udtryk for en problematisk organisering af de pædagogiske situationer, men derimod som udtryk for deres personlige svagheder.

\section{Praktiske undervisningssituationer og elever med etnisk minoritetsbaggrund}

I en række af de arbejdsfællesskaber, som produktionsskolen er bygget op omkring, viser det sig, at elever med anden etnisk baggrund faktisk klarer sig bedre, end når situationen alene hviler på en akademiseret sproglig formidling. Disse situationer kan kendetegnes ved at være struktureret om arbejdssituationer, hvor eleverne gennem deres aktive bidrag er med til i fællesskab at skabe et fælles produkt. Disse arbejdsfællesskaber er langt mere åbne i den forstand at eleverne, både danske og minoritetsunge, kan trække på et dagligdagssprog og de mimetiske ressourcer som eksisterer i form af, at de kan se, hvordan læreren eller de andre udfører de forskellige arbejdsopgaver. Således kan de unge med minoritetsbaggrund bedre orientere sig, og de er langt bedre til at trække erfaringer ind fra andre sammenhænge. I flere tilfælde fremtræder de som elever, der rent faktisk har noget at tilbyde arbejdsfællesskaberne. Mange af eleverne med anden etnisk baggrund synes $\mathrm{i}$ høj grad at være engagerede $\mathrm{i}$ arbejdsfællesskaber uden for skolen, hvilket de aktivt forholder sig til og bruger på produktionsskolen. De ikke-skolastiske erfaringer, som de har, er ofte uformelle og kan både være knyttet til tilfældige personer og familiære relationer. Følgende eksempel er hentet fra 
køkkenværkstedet på Vilstrupgårds Produktionsskole, hvor Omar er i gang med at bage pizzabunde:

Omar kommer ind til Louise og Line. "Jeg skal lige høre, om I putter ost eller kød på først?". Line: "Vi putter ost på først". "Godt. Det er nemlig også sådan, de gør, når de laver pizza nede i byen - det er bedst sådan". Jeg går med ham ind i rummet, hvor der bages. Omar ruller dejen ud. Det ser meget professionelt $u d$, og jeg spørger, om han har prevet det mange gange.

"Jeg har aldrig provet det for", siger han og svinger dejen rundt om armen.

Line er kommet ud: "Du har da arbejdet $i$ et pizzeria ikke"." Nej det har jeg aldrig" siger Omar.

"Jeg har bare set, hvordan de gør på pizzeriaer nede i byen og så lært det derfra. Jeg står altid og kigger på, hvordan de gør, og så er jeg meget selvsikker, så jeg prøver mig bare frem".

Han svinger dejen rundt igen og lægger den derefter ned på bordet, hvorefter han drysser mel ud på dejen og ruller dejen ud igen. Derefter lægger han den over sin arm og banker på den, så melet drysser af. Jeg er meget imponeret over det håndelag, han udviser. Han lægger dejen på en plade og skærer dejen til, så den passer. Resterne af dejen lægger han over til det andet dej og starter på den næste bund.

Eksemplet viser, hvorledes Omar ud fra en uformel og tilfældig situation lærer et håndelag i forhold til pizzabagning, som han inddrager i skolekonteksten og bruger aktivt. Her benytter Omar sig også af de læringsmæssige ressourcer, der ligger i arbejdsfællesskabet, hvor han spørger to andre elever om råd. Vi observerede i mange tilfælde, at eleverne var gode til at bruge hinanden $\mathrm{i}$ forhold til de problemer, der skulle løses i forskellige praktiske arbejdssituationer.

Det næste eksempel er et uddrag fra et interview med Muhammed, hvor han beskriver, hvorledes hans far har lært ham bestemte færdigheder, som vi, via vores observationer forinden, havde set ham udføre.

M: Jeg har arbejdet lang tid med at montere anlæg og sådan nogle ting.

TK: Er det sådan, hoor du prøver dig frem?

M: Nej, det har jeg lart af min far. Min far er mekaniker.

TK: $O k$, så han forklarer dig hoordan?

M: Ja, det er ham, der har lert os det.

TK: Hvordan synes du, din far er til at lære dig ting?

M: Ok. Nej, fordi han har monteret den mange gange foran mig, sådan der. Så jeg sagde til ham: "Er det ikke sådan og sådan, man gør?". Så sagde han: "Jo, det er rigtigt nok". Og siden den dag, der har jeg bare selv monteret den. Og min far gør det ikke mere. Så er det mig, der gør det.

Eksemplet her peger på, at elever med anden etnisk baggrund i nogle tilfælde har lært en del inden de kommer på produktionsskolen, som de rent faktisk kan bruge på værkstederne. At de netop er i stand til at bruge disse ikke-skolastiske erfaringer gør, at de i mange tilfælde fremstår som ressourcepersoner. Netop i kraft af at eleverne har en del erfaringer med fra ikkeskolastiske sammenhænge betyder også, at de, i flere tilfælde, ved mere om specifikke områder end læreren gør, og dermed bidrager til løsning af opgaver, læreren kan have svært ved. Flere gange så vi i forbindelse med vore observationer, at eleverne fik lov til at agere eksperter på områder og instruerede andre elever i, hvordan en problemstilling kunne løses. Følgende eksempel er et uddrag fra et interview med en lærer fra én af produktionsskolerne, hvor vedkommende netop peger på denne tematik som en vigtig læringsressource: 
Lærer: "Jamen det kan jo godt være en scooter, fordi hvis vi tager Muhammed. Han ved næsten alt om en scooter. Jamen, vi ved kun halvdelen af, hoad han ved faktisk, hvis jeg skal være helt ærlig, og jeg kan bruge en halv dag på det, hvor han bruger bare den halve tid på det, og hoor jeg siger: "Jamen Muhammed du ved simpelthen bare så meget om scootere - få den lige til at starte. Jeg tror det er tændingen - jeg ved det ikke," siger jeg så. "Det kan også være en kontakt", og han går simpelthen systematisk frem, og det er han simpelthen bare så god til, og det er da kun en glxde for mig, at han har så gode kompetencer inden for det område, og jeg kan også lære noget af det".

Her ser læreren Muhammed som en klar ressource for arbejdsfællesskabet og giver mulighed for, at han kan bruge sine læringserfaringer fra andre steder i skolens praksis. Samtidigt er han åben for, at Muhammed ved mere, end han gør om bestemte områder. En sådan positionering af eleverne ses sjældent i en traditionel skolepraksis, mens de praktiske arbejdsfællesskaber på produktionsskolerne er med til at give elever med anden etnisk baggrund andre og mere konstruktive deltagelsesmuligheder.

\section{Opsamling og diskussion}

Gennem artiklen har vi peget på, hvorledes praktiske arbejdsfællesskaber giver andre positioner og deltagelsesmuligheder for etniske minoriteter end traditionelle undervisningssituationer. Vi har peget på, at sproget som organiserende princip omkring den traditionelle undervisning, især når det anvendte sprog af forskellige grunde ikke formår at matche elevernes dansksproglige forudsætninger, kan bidrage til at fremstille etniske minoritetselever som knapt så intellektuelt velfungerende. Dette kommer både til udtryk gennem undervisningsformen og undervisningsmaterialerne, som er organiseret i forhold til elever, der mestrer et akademisk orienteret sprog. De mere praktiske arbejdsfællesskaber synes derimod at positionere etniske minoriteter som mere velfungerende unge, idet sprogbrugen her i højere grad nærmer sig dagligdagssproget, og idet de her blandt andet får mulighed for at bruge deres læringserfaringer fra andre kontekster end skolekonteksten.

I forhold til den hidtidige forskning repræsenteret blandt andet af Staunæs (2004) og Mørch (2003) peges der i denne artikel på betydningen af kontekstuelle faktorer i forhold til, hvordan kategorier for etnicitet fremtræder $\mathrm{i}$ forskellige situationer. Fra at fokusere på etniske minoriteter som bærere af problemet, har vi i nærværende artikel rettet fokus mod den historiske tilrettelæggelse af undervisning med sproget som organiserende princip og argumenteret for, at den type læringssituationer ofte på forskellig vis er ufleksible og derfor ikke formår at matche de etniske minoritetselevers sproglige forudsætninger, men i stedet utilsigtet medvirker til at de positioneres som intellektuelt mindre velfungerende. Imidlertid kan det individualiserende syn på elevernes svagheder problematiseres. De etniske minoriteters vanskeligheder kan ved et nærmere eftersyn betragtes som en relationel egenskab ved organiseringen af den pædagogiske situation. Den dominerende individualiserende problemforståelse udelukker i mange tilfælde muligheden for at se de etniske minoriteters vanskeligheder $\mathrm{i}$ et relationelt perspektiv. Problemet opstår således, når skolerne har sit udgangspunkt i kulturneutralitet og dermed undgår at se de forskellige forudsætninger, eleverne kommer med, og dermed undgår at tage højde for det i undervisningen. Praktiske arbejdsfællesskaber synes i højere grad at fungere som bindeled mellem elevernes hverdag og skolens praksis, hvilket gør det nemmere at overføre erfaringer fra den ene kontekst til den anden.

Skismaet mellem traditionel undervisningsform og praktiske arbejdsfællesskaber træder således frem på produktionsskolerne på grund af deres organisering og har givet mulighed for 
at se, hvorledes forskellige organiseringer påvirker de samme elever. Ud fra vore observationer kunne vi se, at eleverne havde forskellige reaktioner på at komme til at fremstå som dårligt fungerende. De mandlige etniske minoriteter reagerede typisk med ballade for at undgå at fremstå som dårligt fungerende, mens de kvindelige elever med anden etnisk baggrund end dansk reagerede med resignation. Men både de mandlige og de kvindelige etniske minoritetselever havde samtidig tilbøjelighed til at godtage rollen som dårligt fungerende via udtalelser som eksempelvis: "Jeg forstår det ikke - jeg kan ikke" eller "Fuck det teori. Jeg fatter ikke en skid, mand". De har således en tendens til at betragte sig selv, og ikke tilrettelæggelsen af undervisningssituationen, som problemet. Dette samspil mellem elev og undervisningssituation kan være en del af forklaringen på det store frafald blandt etniske minoriteter i de erhvervsrettede ungdomsuddannelser.

Derudover observerede vi også, at ikke alene godtog eleverne rollen som dårligt fungerende, men især for de mandlige elever forekom det i flere situationer som om, de nærmest dyrkede den rolle som identitet og søgte bekræftelse for den (se også Kierkegaard \& Nielsen, 2008). Elevernes accept og dyrkelse af at være ikke-velfungerende kan betyde, at skismaet mellem traditionel undervisningsform og praktiske arbejdsfællesskaber bliver endnu større for eleverne, og de derfor bevæger sig endnu længere væk fra de traditionelle undervisningsformer. Dette kan medføre alvorlige problemer, hvis de senere skal indgå i en uddannelsesmæssig sammenhæng, specielt når flere og flere uddannelser akademiseres og intellektualiseres. Udviklingen kan blive selvforstærkende og kan skabe problemer, idet det kan bidrage til konflikter lærer-elev imellem, og dermed bliver der flere negative erfaringer forbundet med de traditionelle undervisningssituationer.

\section{Litteratur}

Alexander K.L. \& Entwistle D.R. (2001). The dropout process in life course perspective: early risk factors at home and school Teachers College Record, vol 103, no 5, pp. 760-822.

Analyseinstituttet "Instant Answer" (2004). Undersøgelser af årsager til "restgruppens" frafald.

Andersen, D. (2005). 4 år efter grundskolen. 19 årige om valg og veje $i$ ungdomsuddannelserne. København: Amternes og kommunernes forskningsinstitut, AKF.

Andersen, O.D. (2001). Frafald i erhvervsuddannelsernes praktikdele - en synteserapport. København: Danmarks Erhvervspædagogiske Læreruddannelse.

Brock, J. \& Gonnsen, L. (2004). Pædagogikken og frafaldet. Undervisningsministeriet (ikke publiceret).

Colding, B. (2005) En sammenligning af udlændinges og danskeres karakterer fra folkeskolens afgangsprøver og på de gymnasiale uddannelser. Baggrundsrapport i Tænketanken om udfordringer for integrationsindsatsen i Danmark.

Gudmundsson, G. \& Jensen, N.R. (2005). Pædagogik for unge med særlige behov - en forskningsbaseret udredning om, "hvad der virker". Danmarks Pædagogiske Universitets Forlag, København. 
Integrationsministeriet (2005) Udlændinge på ungdomsuddannelserne - frafald og faglige kundskaber. Tænketanken om udfordringer for integrationsindsatsen i Danmark i samarbejde med Amternes og Kommunernes Forskningsinstitut. Integrationsministeriet.

Jensen, P. \& Tranæs, T. (2007) PISA Etnisk 2005 Kompetencer hos danske og etniske elver $i$ 9. Klasser $i$ Danmark 2005. Odense: Syddansk Universitetsforlag.

Järvinen, M. \& Mik-Meyer, N. (2005). Observationer i en interaktionistisk begrebsramme. I: Järvinen, M. \& Mik-Meyer, N. (red.) (2005). Kvalitative metoder $i$ et interaktionistisk perspektiv. Interview, observationer og dokumenter. København: Hans Reitzels Forlag.

Kirkegaard, T. \& Nielsen, K. (2008). Kreativitet, produktion og identitet. Undervisningsministeriet. Afdelingen for erhvervsfaglige uddannelser.

Koudahl, P. (2005). Frafald $i$ erhvervsuddannelserne - årsager og forklaringer. Danmarks Pædagogiske Universitet. Undervisningsministeriets temahæfteserie nr. 1, Undervisningsministeriet.

Lave, J. \& Wenger, E. (2003). Situeret læring og andre tekster. København: Hans Reitzels Forlag..

Mehlbye, J., Haagensen, P. \& Halgreen, T. (2000): Et frit valg? Unges overgang fra grundskolen til ungdomsuddannelserne - om danske unge og unge fra etniske minoriteter. København: AKF-forlaget.

Ministeriet for Flygtninge, Indvandrere og Integration (MFII) (2005). Udlandinge på ungdomsuddannelserne - frafald og faglige kundskaber. Ministeriet for Flygtninge, Indvandrere og Integration, Tænketanken om udfordringer for integrationsindsatsen.

Mørch, L.L. (2003) Læring og overskridelse af marginalisering. Studie af unge mænd med etnisk minoritetsbaggrund. Ph.d.-afhandling. København: Danmarks Pædagogiske Universitets Forlag.

Nielsen, K. \& Kvale, S. (2006). The Workplace - a Landscape of Learning. In Antonacopoulou, E., Jarvis, P., Andersen, V., Elkjaer, B., Høyrup, S. (Eds.) Learning, Working and Living, Palgrave Macmillan, (pp. 119-135).

Pedersen, L. T. (2006) Læring og Identitet. Aalborg: Aalborg Universitetsforlag.

Schmidt, G. \& Jacobsen, V. (2000). 20 år i Danmark. En undersøgelse af nydanskeres situation og erfaringer. København, Socialforskningsinstituttet.

Schön, D.A. (1983). The reflective practitioner: How professionals think in action. New York: Basic Books, USA.

Schön, D.A. (1987). Educating the reflective practitioner: Toward a new design for teaching and learning in the professions. London: Jossey Bass.

Sigurjonsson, G. (2002) Dansk vekseluddannelse i støbeskeen. Fra lavstidens mesterlære til moderne dansk vekseluddannelse. Aalborg: Aalborg Universitet, Institut for Kommunikation

Staunæs, D. (2004). Køn, etnicitet og skoleliv. Frederiksberg: Samfundslitteratur. 
UVM (2004): www.uvm.dk/statistik/prodskoler2004.htm?menuid=551015

UVM (2007): www.uddannelsesstatistik.dk/pls/www_ndb/ndb

Varenne, H. \& McDermott, R. (1999) Succesful failure: The school America builds. Boulder, CO: Westview.

Wackerhausen, S. (1999) Det skoalstiske paradigme og mesterlære. I Nielsen, K. og Kvale, S., Mesterlære - læring som social praksis. København: Hans Reitzels Forlag.

\section{Forfattere}

Tanja Kirkegaard er ph.d.-stipendiat på Institut for Kommunikation, Aalborg Universitet. Klaus Nielsen er professor i pædagogisk psykologi på Aarhus Universitet. Kasper Østergaard Linde er rådgivningskoordinator på Albahus. Email (Kirkegaard): tanja.kirkegaard@gmail.com 